\title{
Pengembangan Kerangka Kerja Sosiokultural untuk Membangun Karakter Islami di Program Studi Pendidikan Bahasa Inggris
}

\author{
Astri Hapsari \\ Prodi Pendidikan Bahasa Inggris Universitas Islam Indonesia \\ E-mail: astrihapsari.0@gmail.com
}

\begin{abstract}
Aunique department which integrates Islamic psychology and values within its curriculum, Department of English Language Education Universitas Islam Indonesia develops Islamic learning activity model from Vygotskyan sociocultural perspective in educational psychology. This paper will elaborate how Vygotskyan sociocultural framework shapes the Islamic character building in English language teaching and learning conducted by the lecturers in the classrooms and extracurricular activities conducted by the students, taking references within educational linguistics that understand language from the perspective of sociocultural theory "on the role of language and other sociocultural artefacts in the mediation of human activity and social practice" (Cross, 2009). The aims of the discussion are to connect the dots of sociocultural perspective in practice in language education, Islamic character building, and educational psychology.
\end{abstract}

Keywords: Vygotskyan sociocultural theory, language education, Islamic character building,

\section{Abstrak}

Sebagai sebuah program studi yang memiliki keunikan dengan mengintegrasikan psikologi dan nilai-nilai Islami dalam kurikulum, Program Studi Pendidikan Bahasa Inggris Universitas Islam Indonesia mengembangkan model aktivitas pembelajaran dari perspektif Vygotskian dalam psikologi pendidikan. Naskah publikasi ini akan menjelaskan bagaimana kerangka kerja sosiokultural Vygotsky membangun karakter Islami dalam proses belajar mengajar bahasa Inggris yang dilakukan para dosen di ruangan kelas dan aktivitas-aktivitas ektrakurikuler mahasiswa, dengan mengambil referensi dari paradigma linguistik pendidikan yang memahami bahasa dari persperktif teori sosiokultural, terutama tentang peran bahasa dan artefak sosiokulural lain sebagai mediasi aktivitas manusia dan praktek sosial (Cross, 2009). Tujuan dari pembahasan adalah untuk menghubungkan perspektif sosiokultural dalam praktek pendidikan bahasa, pembangunan karakter Islami dan psikologi pendidikan.

Kata kunci: Teori sosiokultural Vygotsky, Pendidikan bahasa, Pembangunan karakter Islami.

Lev Semyonovich Vygotsky telah menjadi salah satu figur penting dalam bidang keilmuan psikologi di Amerika Serikat sejak publikasi monografnya yang berjudul Thought and Language pada tahun 1962 (Vygotsky, 1978). Dalam psikologi pendidikan, gagasan-gagasan Vygotsky mengenai perkembangan kognitif anak-anak menekankan pentingnya masyarakat dan budaya dalam mendorong pertumbuhan sehingga teorinya kemudian dikenal dengan perspektif sosiokultural (Ormrod, 2009). Kebudayaan memiliki perangkat-perangkat (artefak-artefak) berupa entitas-entitas fisik, simbol-simbol (seperti alfabet, angka) atau kombinasi keduanya. Selain itu, kebudayaan juga memiliki perangkat-perangkat nonfisik yang tidak memiliki landasan fisik apapun yang disebut cognitive tools (Ormond, 2009). Salah satu cognitive tools yang sangat berperan dalam mengembangkan pikiran manusia adalah bahasa (Vygotsky, 1986). 
Di bidang pendidikan bahasa, teori sosiokultural yang bersumber dari Vygotsky (1978) telah mendapat tempat khusus seiring dengan berkembangnya pendekatan komunikatif (communicative approach) dalam proses belajar mengajar di kelas-kelas bahasa (Lantolf dan Appel, 1994; Lantolf, 2014; Lantolf dan Thorne, 2014).Tujuan dari pembahasan naskah publikasi ini adalah untuk menghubungkan perspektif sosiokultural dalam praktek pendidikan bahasa, pembangunan karakter Islami dan psikologi pendidikan dan menggambarkan implementasinya di Program Studi Pendidikan Bahasa Inggris Universitas Islam Indonesia.

\section{Teori Sosiokultural dan Model Struktur Aktivitas Manusia}

Teori sosiokultural memandang bahasa dan artefak sosiokultural berperan memediasi aktivitas manusia dan praktek sosial (Cross, 2009).Tesis sentral dalam teori sosiokultural Vygotsky ini kemudian dikembangkan oleh rekan sezamannya, Leontiev menjadi culturalhistoric activity theory(Leontiev, 1981 dikutip dalam Cross, 2005), yang menggeser penekanan analisis dari tools(bahasa, artefak budaya lainnya dalam konteks pendidikan bahasa) sebagai unit analisis ke aktivitas-aktivitas yang melibatkan tools tersebut (Cross, 2005). Pengembangan pemikiran Vygotsky oleh Leontiev ini kemudian diformulasikan oleh Engeström menjadi sebuah sistem aktivitas dengan model sebagai berikut:

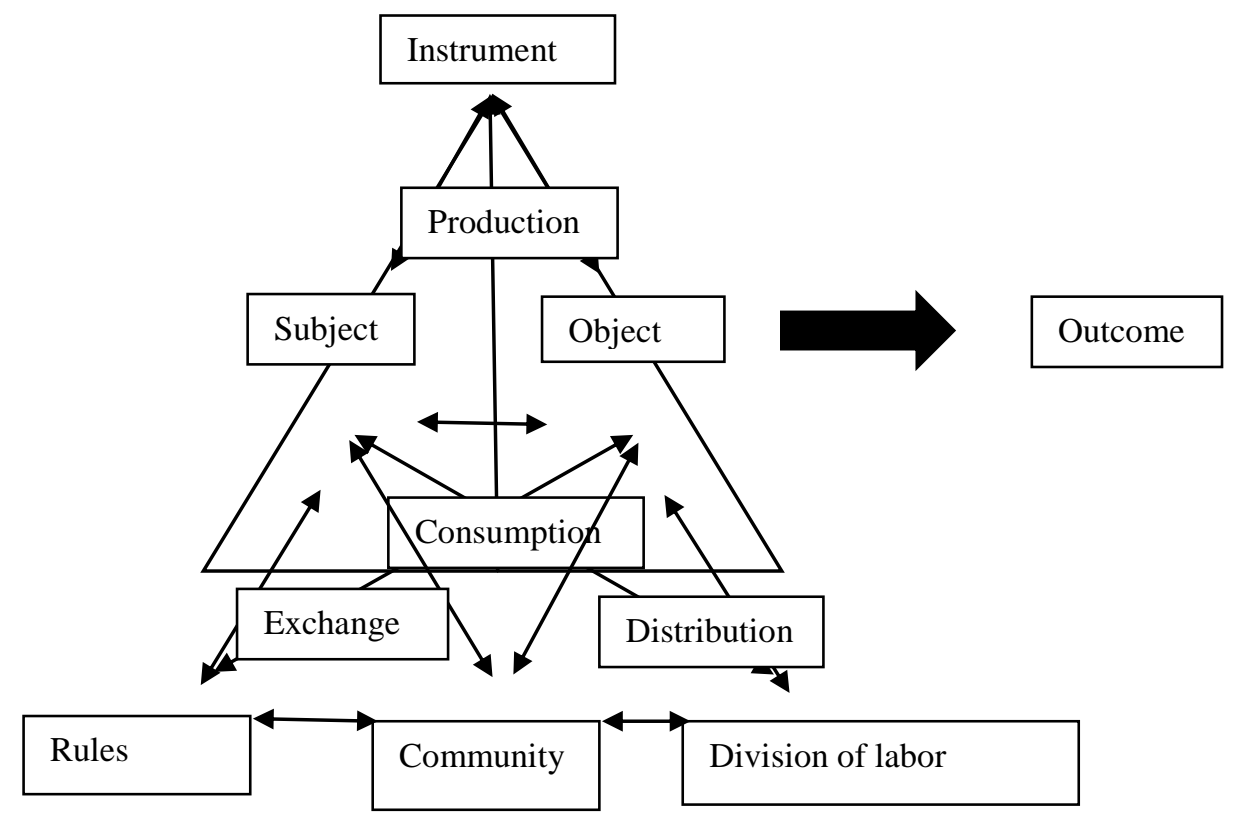

Gambar 1: Struktur Aktivitas Manusia (Engeström, 1987, dikutip dalam Engeström, 2015, hal.2)

Diagram bagian atas menggambarkan tesis sentral Vygotsky mengenai hubungan subject dan object, yang dimediasi instrument (tools) sehingga mencapai hasil tertentu. Diagram bagian bawah adalah perluasan tesis sentral Vygotsky dalam lingkungan sosiokultural dimana produksi terjadi. Perluasan ini menciptakan hubungan pertukaran, konsumsi dan distribusi dalam struktur aktivitas manusia. Dalam konteks proses belajar mengajar bahasa Inggris di Program Studi Pendidikan Bahasa Inggris, maka tesis sentral Vygotsky diwakili dengan dosen sebagai subject, bahasa instruksi dalam kelas dan teknologi pembelajaran yang digunakan sebagai instrumentyang memediasi proses berpikir lebih tinggi (higher order thinking) mahasiswa, yang dalam hal ini berperan sebagai object, sehingga menghasilkan lulusan sarjana pendidikan bahasa Inggris yang sesuai dengan visi, misi, dan tujuan program studi dan universitas (outcome). 
Interaksi subject dan object merupakan aktivitas yang tidak dapat dipisahkan dari sistem aktivitas timbal balik yang lebih besar, sehingga praktek transfer ilmu dalam ruangan kelas pada hakikatnya terkonstruksi secara sosiokultural.

\section{Membangun Karakter Islami (Islamic Character-building) dalam Lingkungan Sosiokutural Institusi Pendidikan Tinggi}

Institusi Pendidikan Tinggi seperti sekolah tinggi, akademi, dan universitas merupakan institusi-institusi yang mendidik kaum intelektual yang akan mengamalkan disiplin keilmuan mereka di dunia kerja. Dalam hal ini, pendidikan karakter (character education) dalah hal yang tidak dapat dipisahkan dalam usaha-usaha untuk membangun karakter (character-building). Dalam perspektif demokrasi Barat, pendidikan karakter, walaupun mengalami pasang surut, telah menjadi bagian sejarah pendidikan yang mendapat tempat khusus. Pendidikan karakter dalam tradisi Barat kontemporer telah berkembang menjadi budaya akademik dengan dukungan etika keutamaan (virtue ethics) di bidang filosofi moral yang sedang populer dan tren terbaru di bidang ilmu pengetahuan sosial, seperti psikologi positif (positive psychology), yang menghidupkan kembali konsep-konsep karakter dan keutamaan (The Jubilee Center, University of Birmingham, 2015).

Dalam perspektif Islam, kaum intelektual bukanlah kaum yang hanya menguasai ilmu pengetahuan dengan akal pikiran atau rasio semata. Selain memiliki kemampuan untuk menyelidiki dan mencari penjelasan logis di balik suatu peristiwa, manusia juga memiliki kemampuan dan kecendrungan untuk mencari makna. Kemampuan intelek manusia bahkan tidak dapat disejajarkan dengan makhluk hidup lainnya maupun komputer ataupun artificial intelligence tercanggih manapun. Zohar dan Marshall (2000) menganalogikan perbedaan kemampuan intelektual manusia dan komputer dalam hal bahasa sebagai berikut: komputerkomputer mungkin dapat memanipulasi sintaks bahasa (mampu mengetahui susunan kata dengan gramatika yang benar), tetapi "hanya manusialah yang memahami semantik, makna susunan kata dan metafora" (hal. 53). Allah SWT berfirman dalam Al-Quran:

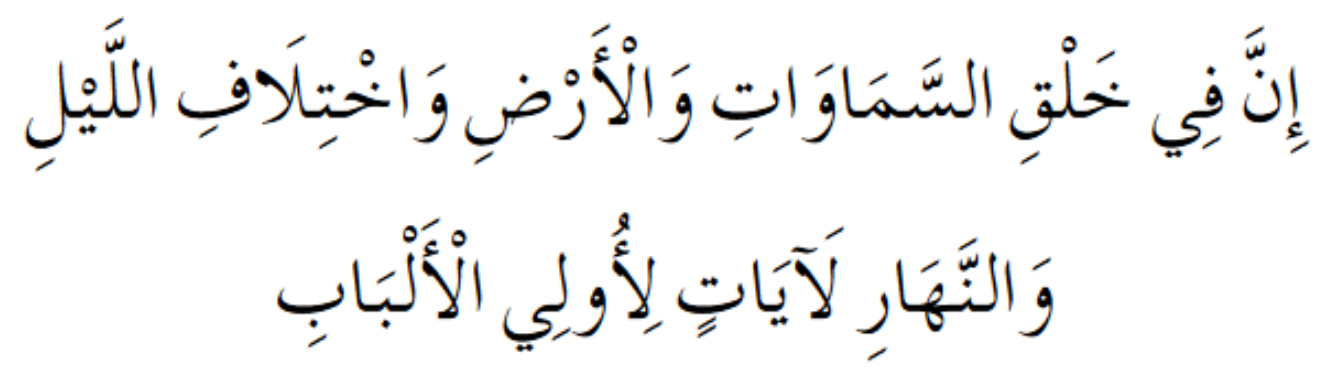

Sesungguhnya dalam penciptaan langit dan bumi, dan silih bergantinya malam dan siang terdapat tanda-tanda bagi orang-orang yang berakal,

(QS: Ali Imran Ayat: 190) 


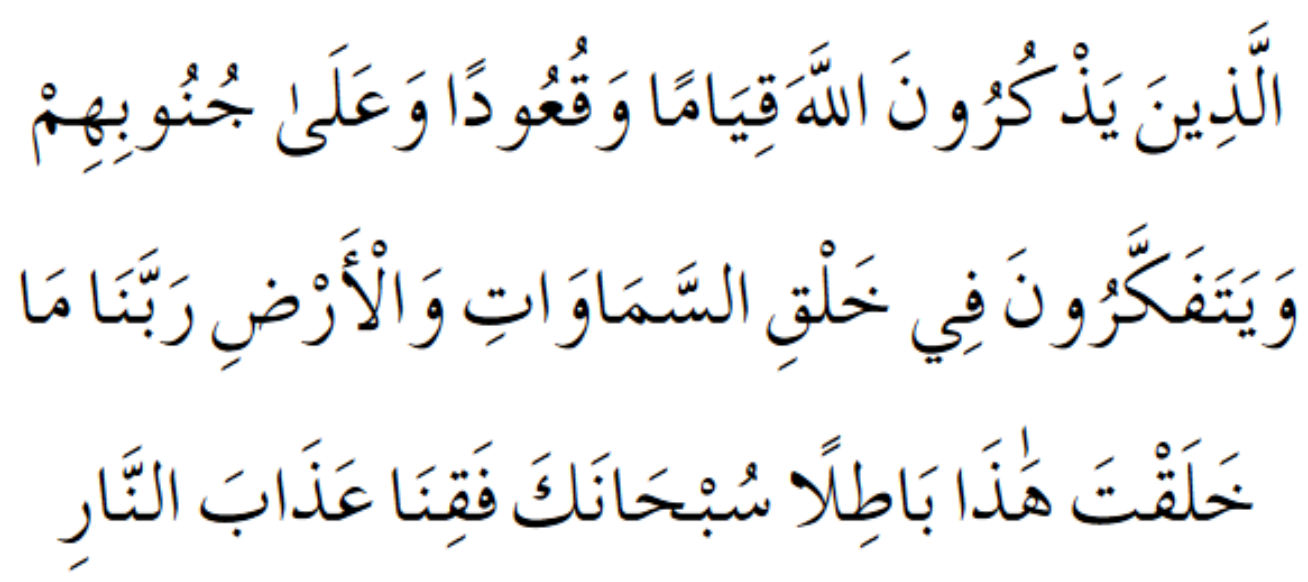

(yaitu) orang-orang yang mengingat Allah sambil berdiri atau duduk atau dalam keadan berbaring dan mereka memikirkan tentang penciptaan langit dan bumi (seraya berkata):

"Ya Tuhan kami, tiadalah Engkau menciptakan ini dengan sia-sia, Maha Suci Engkau, maka peliharalah kami dari siksa neraka.

(QS: Ali Imran Ayat: 191)

Kaum intelektual (ulil-albab) dalam definisi Al-Quran adalah orang-orang yang tidak hanya memikirkan penjelasan di balik penciptaan di langit dan di bumi, tetapi mereka juga adalah orang-orang yang tergerak untuk memaknai tanda-tanda penciptaan dengan mengingat Sang Maha Pencipta. Dengan demikian, institusi pendidikan tinggi yang membangun karakter Islami harus mengintegrasikan nilai-nilai Islami yang memfasilitasi pertumbuhan kecerdasan intelektual, emosional maupun spiritual dalam struktur aktivitas manusia di lingkungan sosial budaya institusi tersebut. Sebagai contoh, Universitas Islam Indonesia (UII) menjabarkan dalam nilai-nilai Islami sebagai nilai-nilai dasar UII yang meliputi aktivitas seluruh warga UII dalam kegiatan kurikuler, ko-kurikuler, dan non kurikuler yang tercantum dalam Rencana Induk Pengembangan UII 2008-2038 berupa:

"keterpaduan antara nilai pengabdian (ibadah) dan keunggulan (excellence). Pengabdian merupakan pengamalan risalah Islam dalam interaksi dengan Allah dan interaksi dengan sesama makhluk. Keduanya harus dikerjakan dalam rangka pengabdian kepada Allah dan mencari keridhaan-Nya yang dijiwai oleh sifat-sifat utama (alfadlilah), yaitu: ikhlas, taqwa, jujur, adil, kerjasama, toleransi, arif, amanah dan tanggung jawab. Keunggulan ditunjukkan dengan sifat-sifat utama (alfadlilah), yaitu: cerdas, disiplin, proaktif, terbuka, kreatif, mandiri, efektif, efisien, dan integratif. Dengan dimilikinya sifat-sifat utama tersebut, maka kehadiran UII akan mendatangkan kemaslahatan bagi alam semesta; yaitu memberikan manfaat dan menjauhkan kemudharatan. Memperhatikan nilai-nilai dasar tersebut, UII memiliki komitmen untuk menghasilkan manusia yang berkualitas (Ulil Albab), yaitu manusia yang berilmu amaliyah, beramal ilmiah serta berakhlakul karimah." (hal. 10-11)

Berdasarkan dokumen tersebut, Universitas Islam Indonesia (UII) telah menjabarkan nilai-nilai keutamaan (virtue) yang dalam terminologi UII disebut sifat-sifat utama (alfadilah) yang menjadi ruh dalam pembangunan karakter Islami (Islamic character-building). 
Apabila landasan pendidikan karakter kontemporer untuk membangun karakter dalam tradisi keilmuan Barat adalah filsafat moral dan psikologi positif, maka landasan pendidikan karakter Islami untuk membangun karakter Islami adalah Al-Quran, Hadis dan psikologi Islam. Namun, dalam membangun karakter Islami, segala nilai-nilai keutamaan dan pencarian akan makna dijiwai dengan persaksian bahwa tiada Tuhan selain Allah dan Muhammad utusan Allah.

Dalam perspektif Model Struktur Aktivitas Manusia Engeström, institusionalisasi nilai-nilai keislaman dalam Rencana Induk Pengembangan UII ini menjadi ruh dalam aspek rules dan berpengaruh dalam struktur aktivitas dalam pertukaran, produksi, konsumsi, maupun distribusi di seluruh fakultas maupun program studi di lingkungan sosiokultural UII.

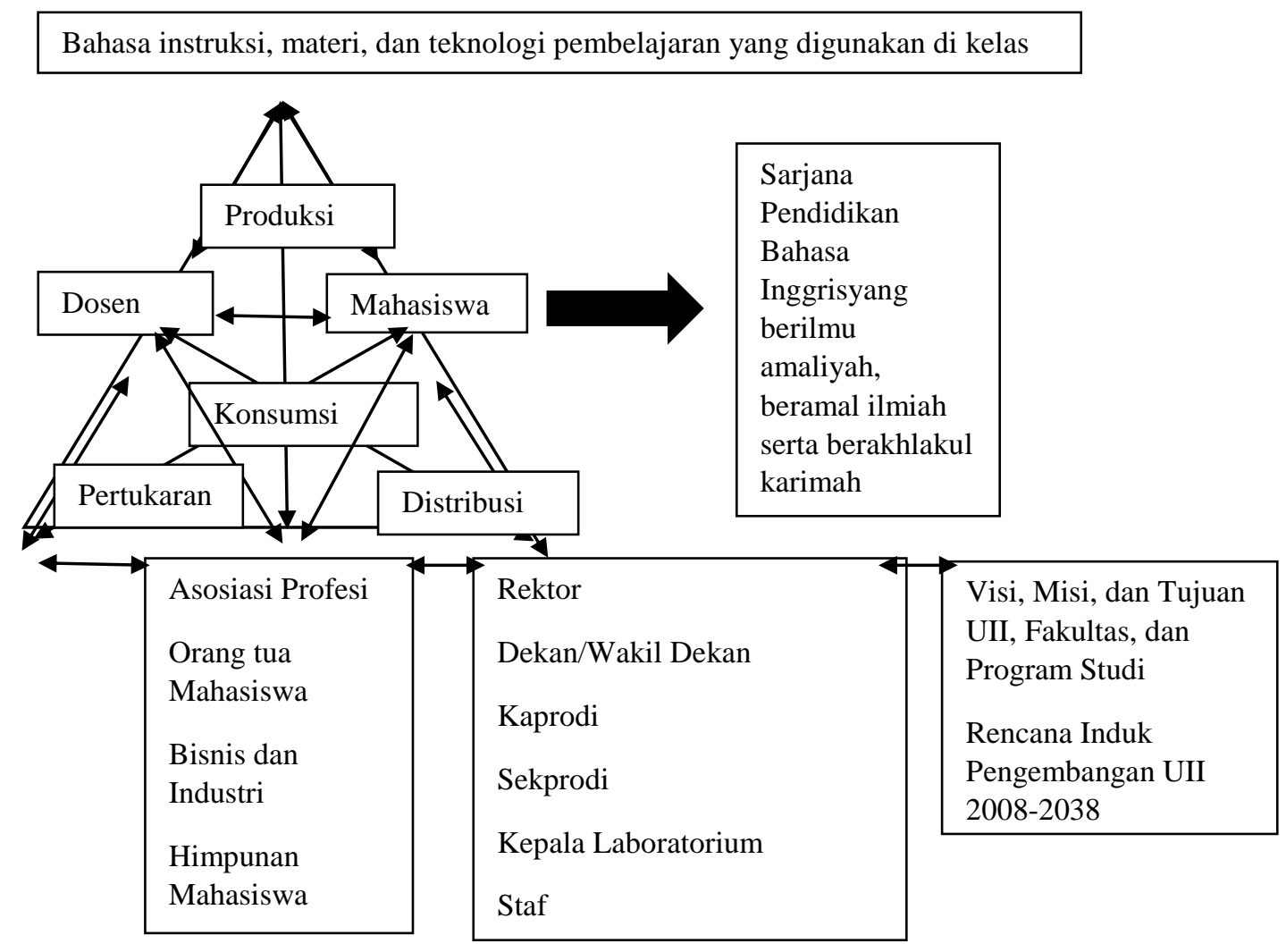

Gambar 2: Kerangka Kerja Sosiokultural di Program Studi Pendidikan Bahasa Inggris UII

\section{Pengembangan Kerangka Kerja Sosiokultural untuk Membangun Karakter Islami di Program Studi Pendidikan Bahasa Inggris.}

Dalam membangun karakter mahasiswa di perguruan tinggi, seorang dosen memiliki peran penting karena proses transfer ilmu pengetahuan sebagian besar terjadi dalam proses belajar mengajar di ruangan kelas. Oleh karena itu, dalam menjelaskan kerangka kerja sosiokultural, dosen menjadi titik sentral dalam proses produksi, konsumsi, distribusi dan pertukaran aktivitas dalam sistem. Di Program Studi Pendidikan Bahasa Inggris, peran sentral para dosen ini tampak dalam proses belajar mengajar bahasa Inggris yang dilakukan para dosen di ruangan kelas dan aktivitas-aktivitas ektrakulrikuler mahasiswa. 


\section{Proses Belajar-Mengajar di kelas-kelas Pendidikan Bahasa Inggris}

Proses belajar mengajar di kelas-kelas Pendidikan Bahasa Inggris mengimplementasikan tesis sentral Vygotsky ; yaitu teori sosiokultural. Paham yang berlandaskan teori ini lebih dikenal dengan konstruktivisme sosial (social constructivism) yang menekankan pentingnya pembelajaran kolaboratif. Vygotsky(1978, hal. 31-75) menyatakan bahwa perkembangan fungsi kognitif yang lebih tinggi pada manusia, contohnya persepsi verbal (verbalized perception) yang membantu mengontrol perhatian secara disadari (voluntary attention) dan penguasaan daya ingat (memory) ,yang pada akhirnya membentuk proses berpikir logis, dipengaruhi oleh dua tahap perkembangan yang berbeda, yaitu level perkembangan aktual (sesuai dengan kematangan fisik dan biologis) dan level perkembangan kultural (kondisi sosiokultural tentang cara bernalar dan berperilaku). Proses belajar secara kolaboratif memungkinkan perkembangan fungsi kognitif pada level yang lebih tinggi karena kondisi sosiokultural yang senantiasa memperbincangkan konten keilmuan dan proses diskusi dalam kelompok akan membantu mahasiswa menginternalisasi ilmu pengetahuan dalam ingatan mereka. Dalam perspektif konstruktivisme sosial ini, setiap mahasiswa diyakini memiliki zona level perkembangan potensial (zone proximal development) yang dapat dicapai melalui interaksi mereka dengan dosen atau interaksi dengan rekan mahasiswa yang bersama-sama melakukan proses belajar secara kolaboratif. Dengan bekerja mengerjakan tugas secara kolaboratif ini maka mahasiswa secara berkelompok akan mampu memahami material dan memecahkan permasalahan tugas secara bersama-sama yang tidak mampu mereka kerjakan dengan level pemahaman mereka secara individual. Ada proses pematangan struktur kognitif ke level yang lebih tinggi pada kondisi sosiokultural belajar mengajar seperti ini.

Untuk membangun karakter Islami, konstruktivisme sosial ini sangat sejalan dengan nilai-nilai Islam. Ada nilai-nilai tanggung jawab sosial yang dibangun dalam proses belajar secara kolaboratif- bahwa apabila seseorang mahasiswa memiliki kapasitas intelektual yang baik, dia memiliki tanggung jawab sosial untuk membagi penguasaan ilmu yang dimilikinya kepada orang lain. Dengan proses berbagi dalam diskusi kelompok, seorang mahasiswa yang masih belum kuat penguasaan ilmunya dididik untuk tidak merasa rendah diri untuk bertanya kepada mahasiswa lainnya yang lebih paham. Dalam hal ini peran dosen akhirnya menjadi fasilitator pembelajaran- dosen tidak menjadi satu-satunya sumber pengetahuan seluruh mahasiswa. Walaupun demikian, dosen tetap berperan untuk memberi keteladanan dalam proses belajar mengajar di ruang kelas - bahwa bahasa instruksi, pengembangan materi dan penggunaan teknologi pembelajaran hendaknya direncanakan agar tidak jauh dari nilai-nilai keislaman.

\section{Aktivitas-aktivitas Ekstrakurikuler Mahasiswa Pendidikan Bahasa Inggris}

Dalam hal aktivitas-aktivitas ekstrakurikuler, mahasiswa Program Studi Pendidikan Bahasa Inggris ada yang memilih aktif di kegiatan kelembagaan di level universitas, seperti Lembaga Eksekutif Mahasiswa (LEM), atau di level fakultas, misalnya organisasi dakwah fakultas Jamaah Fathan Mubina (JAFANA). Untuk tingkat program studi, kegiatan ekstrakurikuler mahasiswa Pendidikan Bahasa Inggris diinsiasi oleh dosen-dosen Pendidikan Bahasa Inggris, misalnya English Speaking Community, English Magazine dan Movie Discussion Club. Kegiatan-kegiatan ekstrakurikuler ini diperlukan untuk memperbanyak paparanbahasa Inggris kepada mahasiswa. Dikegiatan English Speaking Community, misalnya, mahasiswa yang lebih senior belajar untuk menjadi tutor bahasa Inggris bagi juniornya. Tutor English Speaking Community mendesain kursus bahasa Inggris singkat sepuluh kali pertemuan. Di komunitas ini mereka belajar mengelola kursus dan menjadi tutor bahasa. Dosen berperan 
sebagai konsultan material yang dikembangkan mahasiswa. Dalam kegiatan ekstrakurikuler ini mahasiswa dilatih untuk secara bertahap mandiri dan mampu membuat desain kursus bahasa Inggris. Di kegiatan English Magazine, mahasiswa mendapat pendampingan dosen untuk menerbitkan majalah berbahasa Inggris, sedangkan di Movie Discussion Club mahasiswa dilatih untuk memilih film berbahasa Inggris yang jalan ceritanya mengandung pesan yang baik. Kolaborasi antara dosen dan mahasiswa untuk menjalankan kegiatan-kegiatan ekstrakurikuler ini menyediakan zona perkembangan proksimal yang membuat mahasiswa mampu mencapai perkembangan potensialnya. Kesediaan dosen untuk menjadi editor dalam penerbitan English Magazine, misalnya, membuat mahasiswa penulis mendapat kesempatan yang lebih banyak untuk melatih keakuratan gramatikal dan kesesuaian ragam bahasa jurnalistik dalam bahasa Inggris.

Dalam struktur aktivitas, walaupun aktivitas-aktivitas ini bersifat produktif dan melibatkan interaksi langsung dosen dan mahasiswa, tujuannya dapat meluas ke pemenuhan kebutuhan konsumsi komunitas dalam struktur aktivitas sosiokultural Program Studi Pendidikan Bahasa Inggris. Dengan pengalaman yang didapat di kegiatan ekstrakurikuler di English Speaking Community, misalnya, seorang mahasiswa Pendidikan Bahasa Inggris akan memiliki perkembangan potensial untuk mendesain kursus bahasa Inggris untuk bisnis dan industri. Dari segi pertukaran nilai, dosen dapat memainkan peran penting untuk membangun karakter Islami melalui keteladanan sifat-sifat utama (al fadilah) seperti yang dirumuskan dalam visi, misi, tujuan dan rencana induk pengembangan universitas. Keteladanan ini diperkuat dengan distribusi peran dosen dalam jabatan struktural program studi (kepala program studi dan sekretaris program studi) untuk memperkuat komitmen seluruh dosen terhadap nilai-nilai keislaman.

\section{Penutup}

Kerangka sosiokultural memungkinkan untuk menggeser penekanan analisis dari tools (bahasa, artefak budaya lainnya dalam konteks pendidikan bahasa) sebagai unit analisis ke aktivitas-aktivitas yang melibatkan tools tersebut. Oleh karena itu, pengembangan kerangka kerja sosiokultural untuk membangun karakter Islami di Program Studi Pendidikan Bahasa Inggris dapat dijelaskan dengan perspektif konstruktivisme sosial dan model teori aktivitas manusia sebagai perluasan tesis sentral Vygotsky. Implementasi konstruktivisme sosial yang melibatkan nilai-nilai keIslaman tampak dalam proses belajar mengajar di kelas dan pendampingan kegiatan ekstrakurikuler. Aktivitas-aktivitas ini diharapkan dapat mewujudkan cita-cita Program Studi Pendidikan Bahasa Inggris UII , yaitu menghasilkan Sarjana Pendidikan Bahasa Inggris yang berilmu amaliyah, beramal ilmiah serta berakhlakul karimah.

\section{Daftar Pustaka}

Al-Quran.

Cross, R. (2005). Making Sense of the Eclectic: Conceptualising Teacher Practice in the Communicative Classroom, Babel. 40(2), 16-38.

Cross, R. (2009). A Sociocultural Framework for Language Policy and Planning, Language Problems amd Language Planning. 33(1), 22-42.

Cross, R. (2010). Language Teaching as Sociocultural Activity: Rethinking Language Teacher Practice, The Modern Language Journal. 94(3) 43.4-452. 
Engeström, Y. (2015). Activity Theory and Expansive Design. Diunduh pada 18 Januari 2015, dariprojectfinal.interactionivrea.org/20042005/SYMPOSIUM\%202005/communication\%2 Omaterial/ACTIVITY\%20THEORY\%20AND\%20DESIGN_Engestrom.pdf

Hapsari, A. (2014). Akhlaq Al-Karimah dalam Profesi Keilmuan Pendidikan Bahasa Inggris, Tugas Akhir Studi Intensif Al-Quran dan Dakwah Islam, tidak diterbitkan, Universitas Islam Indonesia.

Lantolf, J.P ., \& Appel, G. (1994). Vygotskian Approaches to Second Language Research. Connecticut: Ablex Publishing.

Lantolf, J.P. (2014). Sociocultural Theory and Second Language Learning (Edisi kesepuluh). Oxford: Oxford University Press.

Lantolf, J.P., \& Thorne, S.L. (2014). Sociocultural Theory and the Genesis of Second Language Development (Edisi kedelapan). Oxford: Oxford University Press.

Ormrod, J.E. (2009). Psikologi Pendidikan: Membantu Siswa Tumbuh dan Berkembang (Edisi Keenam). Jakarta: Penerbit Erlangga.

The Jubilee Center for Character and Virtue. (2015). A Framework for Character Education in Schools. University of Birmingham.

Universitas Islam Indonesia. (2008). Rencana Induk Pengembangan Universitas 2008-2038. Universitas Islam Indonesia.

Vygotsky, L.S. (1978). Mind in Society: The Development of Higher Psychological Processes. United States of America: Harvard University Press.

Vygotsky, L.S. (1986). Thought and Language. United States of America: Massachusetts Institute of Technology Press.

Zohar, D., \& Marshall, I. (2000). SQ: Memanfaatkan Kecerdasan Spiritual dalam Berpikir Integralistik dan Holistik untuk Memaknai Kehidupan. Bandung: Mizan Pustaka 